\title{
EM MEMÓRIA DO PROF. DR. REMI KLEIN
}

Pesquisador da área de Educação e Religião na Escola Superior de Teologia em São Leopoldo no Rio Grande do Sul que desde o início colaborou sistematicamente com a Revista Relegens Thréskeia como autor, avaliador e membro do Conselho Científico deste periódico. Falecimento ocorreu em 03 janeiro de 2020. Agradecido por sua contribuição especialmente no campo do Ensino Religioso.

Os editores 